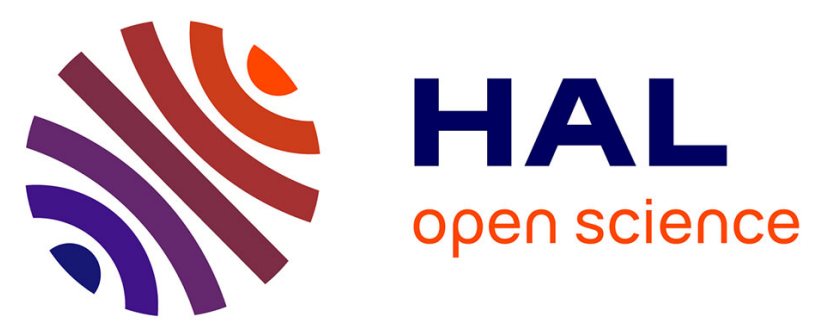

\title{
Syntectonic carbonation during synmagmatic mantle exhumation at an ocean-continent transition
}

Rémi Coltat, Philippe Boulvais, Yannick Branquet, J. Collot, M.E. Epin, G. Manatschal

\section{- To cite this version:}

Rémi Coltat, Philippe Boulvais, Yannick Branquet, J. Collot, M.E. Epin, et al.. Syntectonic carbonation during synmagmatic mantle exhumation at an ocean-continent transition. Geology, 2019, 47 (2), pp.183-186. 10.1130/G45530.1 . insu-01987341

\section{HAL Id: insu-01987341 https://hal-insu.archives-ouvertes.fr/insu-01987341}

Submitted on 9 Dec 2019

HAL is a multi-disciplinary open access archive for the deposit and dissemination of scientific research documents, whether they are published or not. The documents may come from teaching and research institutions in France or abroad, or from public or private research centers.
L'archive ouverte pluridisciplinaire HAL, est destinée au dépôt et à la diffusion de documents scientifiques de niveau recherche, publiés ou non, émanant des établissements d'enseignement et de recherche français ou étrangers, des laboratoires publics ou privés. 
Publisher: GSA

Journal: GEOL: Geology

DOI:10.1130/G45530.1

1 Syn-tectonic carbonation during syn-magmatic mantle

2 exhumation at an ocean-continent transition

3 Rémi Coltat ${ }^{1}$, P. Boulvais ${ }^{1}$, Y. Branquet ${ }^{1,2}$, J. Collot ${ }^{1}$, M.E. Epin ${ }^{3}$, and Gianreto

$4 \quad$ Manatschal ${ }^{3}$

$5{ }^{1}$ Université Rennes, CNRS, Géosciences Rennes, UMR 6118, F-35000 Rennes, France

$6 \quad{ }^{2}$ Institut des Sciences de la Terre d'Orléans, UMR 7327, Université Orléans, 45234

7 Orléans, France

$8{ }^{3}$ Institut de Physique du Globe de Strasbourg, EOST-CNRS UMR 7516, Université

9 Strasbourg, 67084 Strasbourg, France

10 ABSTRACT

11 A Jurassic extensional detachment associated with carbonated serpentinites and

12 basalts is preserved at Falotta (Platta nappe, southeastern Switzerland). Structural data

13 indicates that fluid circulation occurred during late increments of extension along the

14 detachment plane, separating serpentinites from basalts. The homogeneity of the isotopic

15 signatures $\left(\delta^{18} \mathrm{O} \sim 16 \%\right.$ and $\delta^{13} \mathrm{C}$ centered on $0-1 \%$ ) can be best explained by a single,

16 sudden seawater-derived carbonation event at temperatures of $\sim 100{ }^{\circ} \mathrm{C}$. Carbonation was

17 focused in the high permeability zone along the detachment. Our model yields new

18 insights for carbonation processes related to mantle exhumation.

\section{INTRODUCTION}

20 An important discovery in the study of passive margins was the recognition of

21 extensional detachments and mantle exhumation in the most distal parts of magma-poor

22 systems (Boillot et al., 1987). These structures resemble oceanic detachments that have 
Publisher: GSA

Journal: GEOL: Geology

DOI:10.1130/G45530.1

23 been observed at mid-ocean ridges (MacLeod et al., 2002; Cannat et al., 2009). MacLeod

24 et al. (2002) showed that large volumes of seawater interacted with the exhuming mantle

25 resulting in serpentinization of the uppermost $6 \mathrm{~km}$ of the exhumed mantle domain.

26 While hydrothermal cells lead to mineralization in the exhumed mantle $(\sim 1-3 \mathrm{~km}$;

27 McCaig et al., 2007), ophicalcites develop within serpentinites close to the seafloor

28 (Weissert and Bernoulli, 1984). Characterizing such shallow fluid-rock interactions is

29 necessary to understand the chemical exchanges between the mantle and seawater

30 reservoirs and the mass budgets involved in metal deposition $(\mathrm{Fe}, \mathrm{Cu}, \mathrm{Zn})$ close to or at

31 the seafloor.

32 In this paper, we present structural and geochemical data on the carbonation

33 associated with a well-preserved extensional detachment system exposed at Falotta in the

34 Platta nappe (southeastern Switzerland). We show that syn-tectonic carbonation occurred

35 during syn-magmatic mantle exhumation.

\section{GEOLOGICAL SETTING}

37 The Platta nappe, exposed in the southeastern Swiss Alps, hosts remnants of the

38 Jurassic Alpine Tethys Ocean Continent Transition (OCT; Fig. 1A). East-west-directed

39 regional extension, accommodated along mantle detachment faults (Desmurs et al.,

40 2001), was accompanied by mafic magmatism dated at $161 \mathrm{Ma}$ (Schaltegger et al., 2002).

41 The Platta nappe is primarily composed of serpentinized mantle rocks and mafic rocks.

42 The serpentinites are carbonated at their paleo-surface, forming fracture-filling

43 ophicalcites (terminology of Bernoulli and Weissert, 1985). Tectono-sedimentary

44 carbonated mantle breccias (ophiolite breccias of Bernoulli and Weissert, 1985) occur

45 above the exhumed mantle. Mafic volcanic rocks (hyaloclastites, pillows, and lava flows) 
Publisher: GSA

Journal: GEOL: Geology

DOI:10.1130/G45530.1

46 overlie the ophicalcites. The exhumed mantle rocks, breccias and basalts are capped by

47 the Radiolarian Chert Formation dated between 166 and 147 Ma (Bill et al., 2001).

48 PETROGRAPHIC AND STRUCTURAL DATA

49 At Falotta, three lithological units can be distinguished that are from bottom to

50 top: serpentinites, ophicalcites, and basalts (Figs. 1B, 2A, and 3A). The serpentinites

51 consist of cataclasites with preserved serpentinite lenses crosscut by green serpentine

52 veins, gradually evolving upwards to a fault gouge (see also Picazo et al., 2013; Pinto et

53 al., 2015). The ophicalcites consist of, from bottom to top, (1) fracture-filling ophicalcites

54 with veins of fibrous calcite, and (2) foliated ophicalcites. The latter consist of large

55 anastomosing and foliated carbonate shear bands (SBs) developed in serpentinite breccias

56 and around preserved lenses of various sizes (Fig. 2A). The sub-horizontal foliation,

57 broadly $\mathrm{N}^{\circ} 20$ in strike, is defined by actinolite, carbonate, and minor talc and chlorite.

58 Carbonate veins mimic the foliation. The basalt unit contains foliated hyaloclastites,

59 foliated basalts, veined basalts and massive basalts further up-section (Figs. 2A and 3A).

60 The foliation is defined by amphibole and chlorite and displays the same strikes and dips

61 as those observed in the foliated ophicalcites. The basalts are extensively epidotized and

62 chloritized along ribbons near the base.

63 Whereas carbonation may be locally massive and pervasive, replacing serpentinite

64 clasts and matrix, it is expressed throughout the whole section by veins and shear bands

65 (Fig. 3A). Only calcite, white to greyish in color, is observed. The extensional or hybrid

66 shear extensional character of the veins is indicated by fibrous habits of calcite filling and

67 wall rock offsets with calcite being the latest phase to crystallize (Figs. 2B-2E).

68 Extensional veins $(\mathrm{EVs})$ in the serpentinites and ophicalcites contain coarse calcite (up to 
Publisher: GSA

Journal: GEOL: Geology

DOI:10.1130/G45530.1

69 several millimeters) and minor amphibole and chlorite at their rims. The EVs crosscut the

70 serpentine veins (Fig. 2B). In the basalts, veins consisting of epidote, quartz, chlorite, and

71 albite, defining a greenschist paragenesis, are filled by late calcite (Fig. 2C). Hybrid shear

72 extensional veins (SVs) in the serpentinites and ophicalcites are filled with tiny calcite

$73(\sim 10-50 \mu \mathrm{m})$ and actinolite. Close to the contact with the basalts talc and hydro-andradite

74 (garnet composition specified by scanning electron microscopy [SEM] analyses) are

75 found in veins. In the basalts, sparitic to micro-sparitic calcite is associated with

76 actinolite, iron oxides, talc, and hydro-andradite. Calcitic shear bands found in the

77 serpentinites and ophicalcites are composed of tiny calcite, actinolite, and minor chlorite,

78 leaving clasts made of serpentinite, serpentine, pyroxene, spinel, and magnetite. Within

79 the shear bands, the lack of dynamic recrystallization of the carbonate grains and the

80 cracks found in the grains argue for a cataclastic fabric (Fig. 2D). Locally, jogs between

81 calcitic shear veins form pull-apart structures filled with fibrous calcite (Fig. 2E).

82 Vein orientations and dips are plotted in Figure 3B. Throughout the section,

83 calcite fibers are sub-horizontal and oriented east-west. SVs dip $\sim 40-50^{\circ}$ either to the

84 east or to the west, whereas EVs steeply dip $\sim 70-80^{\circ}$. At the base of the fracture-filling

85 ophicalcites, $\mathrm{SVs}$ strike $\mathrm{N}^{\circ} 160$, whereas EVs have an $\mathrm{N}^{\circ} 0$ orientation on average (Fig.

$863 \mathrm{~B})$. EVs at the top of the fracture-filling ophicalcites trend $\mathrm{N}^{\circ} 160$. In the foliated

87 ophicalcites, SVs and EVs roughly trend $\mathrm{N}^{\circ} 30$ (Fig. 3B). In the basalts, EVs are $\mathrm{N}^{\circ} 30$

88 and $\mathrm{SV}$ s trend $\mathrm{N}^{\circ} 40$.

89 STABLE ISOTOPE COMPOSITIONS

$90 \quad$ The $\delta^{18} \mathrm{O}$ and $\delta^{13} \mathrm{C}$ values of calcite are homogenous throughout the section with

91 no significant differences for the different types of veins and shear bands (Fig. 3C, 
Publisher: GSA

Journal: GEOL: Geology

DOI: $10.1130 / \mathrm{G} 45530.1$

92 Appendix DR2 in the GSA Data Repository $\left.{ }^{1}\right)$. The $\delta^{18} \mathrm{O}$ values are centered at $\sim 16.0 \% \pm$

$93 \quad 0.3 \%$ (with a range of $15.4-17.0 \%$ ). The $\delta^{13} \mathrm{C}$ values are slightly more dispersed with

94 values between $-0.44 \%$ and $+2.12 \%$.

95 DISCUSSION

96 Jurassic Carbonation from Seawater

97 A recurring problem when dealing with Jurassic extensional events in the

98 European Alps is to assess the importance of the Alpine overprint (Weissert and

99 Bernoulli, 1984; Früh-Green et al., 1990). There are several arguments for a Jurassic

100 carbonation from seawater, with no Alpine deformation and metamorphic overprint nor

101 isotopic resetting.

102 (1) Sub-vertical calcitic veins with east-west sub-horizontal fibers, together with

103 conjugate hybrid shear extensional veins with normal sense of shear, are indicative of

104 horizontal stretching/extension during carbonation. Normal shear bands in foliated

105 ophicalcites and conjugate hybrid shear extensional veins are symmetric systems

106 diagnostic of coaxial strain. These features, together with the lack of reverse shears

107 on the outcrop (Fig. 2A), are compatible with extensional deformation rather than

108 Alpine thrusting. Notably the structural pattern of veining is similar to veining

109 associated with slip along detachment faults (e.g., Mehl et al., 2005).

110 (2) The overall east-west extension during Jurassic exhumation is consistent with the

111 orientations of carbonate veins and fibers documented here (Froitzheim and

112 Manatschal, 1996). 
Publisher: GSA

Journal: GEOL: Geology

DOI: $10.1130 / \mathrm{G} 45530.1$

113 (3) The presence of hydro-andradite suggests precipitation during oceanic

114 hydrothermalism rather than during regional Alpine metamorphism (Gutzmer et al., 115 2001).

116 (4) One would expect that calcite crystals with variable habits (small versus large veins, 117 minute veins versus pluri-metric ophicalcitized zones, veins hosted in basalts and 118 serpentinites) display variable $\delta^{18} \mathrm{O}$ signatures, but they have identical $\delta^{18} \mathrm{O}$ values.

119 This is inconsistent with recrystallization nor with isotopic exchange with host rocks 120 during a long-lived metamorphic event (see also Eppel and Abart, 1997).

121 (5) The $\delta^{13} \mathrm{C}$ values centered at $0-1 \%$ are entirely consistent with typical marine

122 carbonates (Bach et al., 2011) and broadly fit with other Mesozoic, marine-related 123 ophicalcite occurrences from the Alpine realm (Appendix DR2).

\section{Hydrothermal and Syn-Tectonic Carbonation}

125 Considering the large thickness $(\sim 10 \mathrm{~m}$; Fig. 3A) and the large carbonate content

126 of the ophicalcites, we can infer that seawater is an infinite isotopic reservoir in the fluid-

127 rock interaction system. Hence, we can evaluate the precipitation temperature of calcite

128 from seawater. Taking $\delta^{18} \mathrm{O}_{\mathrm{SW}}=0 \%$ and using the fractionation factor of Kim and

129 O’Neil (1997), we obtain $90-105^{\circ} \mathrm{C}$, a range considerably higher than the typical

130 temperatures of carbonate precipitation at present seafloor $\left(\sim 0-15{ }^{\circ} \mathrm{C}\right.$; Bach et al., 2011 ;

131 Alt and Shanks, 2003) or measured at the Iberian margin ( 19-44 ${ }^{\circ} \mathrm{C}$; Agrinier et al.,

132 1996; Schwarzenbach et al., 2013).

133 The remarkable isotopic homogeneity, i.e., homogeneous temperature,

134 documented in this study compared to other ophicalcites (Appendix DR2) implies that

135 carbonation occurred as a dramatic, sudden event, the mechanism of precipitation being 
Publisher: GSA

Journal: GEOL: Geology

DOI:10.1130/G45530.1

136 unknown to date. Serpentinite breccias, formed during exhumation and subsequent

137 sedimentary reworking over exhumed mantle correspond to a high permeability zone

138 above which basalts were emplaced and underwent syn-emplacement greenschist

139 alteration (Fig. 4, stage I). Both the overlying massive and strongly altered basalts and the

140 underlying serpentinite gouges correspond to a low-permeability zone. The influx of

141 seawater-derived hydrothermal fluids in the high-permeability zone triggered

142 carbonation. The mechanisms of heating and downward circulation of seawater are likely

143 comparable to those described for ultramafic-hosted hydrothermal systems leading to

144 black smoker-type mineralizations or carbonate chimneys (e.g., McCaig et al., 2007; Alt

145 et al., 2018). In the regional context of mantle exhumation, a positive feedback occurred

146 between fluid flow and the extensional reactivation of the detachment plane. Indeed, even

147 if the amount of slip may have been limited, it enhanced dynamic permeability (stage II).

148 Epidote veins in the basalts were re-opened and calcite veins formed in the serpentinites,

149 all displaying orientations consistent with regional extension.

150 The present model contrasts with previous ones assuming that carbonation of

151 serpentinized mantle occurs along the detachment plane during mantle exhumation or

152 under static conditions at the seafloor in the absence of magma (e.g. Lost City

153 hydrothermal field at MAR; Kelley et al., 2001). The coincidence of carbonation and

154 magmatism along present-day fault zones is poorly constrained due to the lack of access

155 to such outcrop. We propose that syn-tectonic carbonation along reactivated detachment

156 segment in relationship with overlying basalts may be an important contribution to

157 oceanic hydrothermal systems, including those leading to metal deposition, and may

158 likely be more widespread than previously thought. 
Publisher: GSA

Journal: GEOL: Geology

DOI:10.1130/G45530.1

159

\section{CONCLUSIONS}

160 Syn-tectonic carbonation along the Jurassic Falotta detachment (Swiss Alps)

161 resulted from the infiltration of hot seawater $\left(\sim 100{ }^{\circ} \mathrm{C}\right)$ into the high-permeability zone at

162 the top of exhumed serpentinites. The homogeneity of isotopic compositions pleads for a

163 sudden, short-lived fluid circulation. Extensional reactivation of the detachment plane,

164 with limited slip during magma emplacement, was favored by fluid-related weakening,

165 with a positive feedback between deformation-induced dynamic permeability and fluid

166 influx.

167 ACKNOWLEDGMENTS

168 This work was funded through a grant from Petrobras to G. Manatschal and from

169 the CNRS-INSU (CESSUR) to P. Boulvais. This work was improved by two anonymous

170 reviewers and Laurent Jolivet. S. Picazo, P. Gautier, and K. Gallagher are thanked for

171 fruitful discussions.

\section{REFERENCES CITED}

173 Agrinier, P., Cornen, G., and Beslier, M.O., 1996, Mineralogical and oxygen isotopic

174 features of serpentinites recovered from the ocean/continent transition in the Iberia

175 Abyssal Plain: Proceedings of the Ocean Drilling Program, Scientific Results, v. 149,

176 p. 541-552, College Station, Texas, Ocean Drilling Program,

177 https://doi.org/10.2973/odp.proc.sr.149.223.1996

178 Alt, J.C., and Shanks, W.C., 2003, Serpentinization of abyssal peridotites from the

179 MARK area, Mid-Atlantic Ridge: Sulfur geochemistry and reaction modelling:

180 Geochimica et Cosmochimica Acta, v. 67, p. 641-653,

$181 \quad$ https://doi.org/10.1016/S0016-7037(02)01142-0. 
Publisher: GSA

Journal: GEOL: Geology

DOI: $10.1130 / \mathrm{G} 45530.1$

182 Alt, J., Crispini, L., Gaggero, L., Levine, D., Lavagnino, G., Shanks, P., and Gulbransen,

183 C., 2018, Normal faulting and evolution of fluid discharge in a Jurassic seafloor

184 ultramafic-hosted hydrothermal system: Geology, v. 46, p. 523-526,

$185 \quad$ https://doi.org/10.1130/G40287.1.

186 Bach, W., Rosner, M., Jöns, N., Rausch, S., Robinson, L.F., Paulick, H., and Erzinger, J.,

187 2011, Carbonate veins trace seawater circulation during exhumation and uplift of

188 mantle rock: Results from ODP Leg 209: Earth and Planetary Science Letters,

189 v. 311 , p. 242-252, https://doi.org/10.1016/j.epsl.2011.09.021.

190 Bernoulli, D., and Weissert, H., 1985, Sedimentary fabrics in Alpine ophicalcites, south

191 Pennine Arosa zone, Switzerland: Geology, v. 13, p. 755-758,

192 https://doi.org/10.1130/0091-7613(1985)13<755:SFIAOS>2.0.CO;2.

193 Bill, M., O’Dogherty, L., Guex, J., Baumgartner, P.O., and Masson, H., 2001, Radiolarite

194 ages in Alpine-Mediterranean ophiolites: Constraints on the oceanic spreading and

195 the Tethys-Atlantic connection: Geological Society of America Bulletin, v. 113,

196 p. 129-143, https://doi.org/10.1130/0016-

$197 \quad$ 7606(2001)113<0129:RAIAMO>2.0.CO;2.

198 Boillot, G., et al., 1987, Tectonic denudation of the upper mantle along passive margins;

199 a model based on drilling results (ODP Leg 103, western Galicia margin, Spain):

200 Tectonophysics, v. 132, p. 335-342, https://doi.org/10.1016/0040-1951(87)90352-0.

201 Cannat, M., Sauter, D., Escartin, J., Lavier, L., and Picazo, S., 2009, Oceanic corrugated

202 surfaces and the strength of the axial lithosphere at slow spreading ridges: Earth and

203 Planetary Science Letters, v. 288, p. 174-183,

204 https://doi.org/10.1016/j.epsl.2009.09.020. 
Publisher: GSA

Journal: GEOL: Geology

DOI:10.1130/G45530.1

205 Decarlis, A., Gillard, M., Tribuzio, R., Epin, M.E., and Manatschal, G., 2018, Breaking

206 up continents at magma-poor rifted margins: A seismic vs. outcrop perspective:

207 Journal of the Geological Society, https://doi.org/10.1144/jgs2018-041 (in press).

208 Desmurs, L., Manatschal, G., and Bernoulli, D., 2001, The Steinmann Trinity revisited:

209 Mantle exhumation and magmatism along an ocean-continent transition: The Platta

210 nape, eastern Switzerland, in Wilson, R.C.L., et al., eds., Non-Volcanic Rifting of

211 Continental Margins: A Comparison of Evidence from Land and Sea: The

212 Geological Society of London Special Publications, v. 187, p. 235-266,

213 https://doi.org/10.1144/GSL.SP.2001.187.01.12.

214 Eppel, H., and Abart, R., 1997, Grain-stable isotope disequilibrium during fluid-rock

215 interaction. 2: An example from the penninic-austroalpine tectonic contact in eastern

216 Switzerland: American Journal of Science, v. 297, p. 707-728,

217 https://doi.org/10.2475/ajs.297.7.707.

218 Froitzheim, N., and Manatschal, G., 1996, Kinematics of Jurassic rifting, mantle

219 exhumation, and passive-margin formation in the Austroalpine and Penninic nappes

220 (eastern Switzerland): Geological Society of America Bulletin, v. 108, p. 1120-1133,

221 https://doi.org/10.1130/0016-7606(1996)108<1120:KOJRME>2.3.CO;2.

222 Früh-Green, G.L., Weissert, H., and Bernoulli, D., 1990, A multiple fluid history in

223 Alpine ophiolites: Journal of the Geological Society, v. 147, p. 959-970,

224 https://doi.org/10.1144/gsjgs.147.6.0959.

225 Gutzmer, J., Pack, A., Lüders, V., Wilkinson, J.J., Beukes, N.J., and van Niekerk, H.S.,

2262001 , Formation of jasper and andradite during low-temperature hydrothermal 
Publisher: GSA

Journal: GEOL: Geology

DOI:10.1130/G45530.1

seafloor metamorphism, Ongeluk formation, South Africa: Contributions to

Mineralogy and Petrology, v. 142, p. 27-42, https://doi.org/10.1007/s004100100270.

229 Kim, S.T., and O'Neil, J.R., 1997, Equilibrium and nonequilibrium oxygen isotope

230 effects in synthetic carbonates: Geochimica et Cosmochimica Acta, v. 61, p. 3461$231 \quad 3475$, https://doi.org/10.1016/S0016-7037(97)00169-5.

232 Kelley, D.S., et al., 2001, An off-axis hydrothermal vent field near the Mid-Atlantic

233 Ridge at $30^{\circ}$ N: Nature, v. 412, p. 145-149, https://doi.org/10.1038/35084000.

234 McCaig, A.M., Cliff, R.A., Escartin, J., Fallick, A.E., and McLeod, C.J., 2007, Oceanic

235 detachment faults focus large volumes of black smoker fluids: Geology, v. 35,

236 p. 935-938, https://doi.org/10.1130/G23657A.1.

237 MacLeod, C.J., et al., 2002, Direct geological evidence for oceanic detachment faulting:

238 The Mid-Atlantic Ridge, $15^{\circ} 45^{\prime}$ N: Geology, v. 30, p. 879-882,

239 https://doi.org/10.1130/0091-7613(2002)030<0879:DGEFOD>2.0.CO;2.

240 Mehl, C., Jolivet, L., and Lacombe, O., 2005, From ductile to brittle: Evolution and

241 localization of deformation below a crustal detachment (Tinos, Cyclades, Greece):

242 Tectonics, v. 24, p. 1-23, https://doi.org/10.1029/2004TC001767.

243 Picazo, S., Manatschal, G., Cannat, M., and Andréani, M., 2013, Deformation associated

244 to exhumation of serpentinized mantle rocks in a fossil Ocean Continent Transition:

245 The Totalp unit in SE Switzerland: Lithos, v. 175-176, p. 255-271,

246 https://doi.org/10.1016/j.lithos.2013.05.010.

247 Pinto, V.H.G., Manatschal, G., Karpoff, A.M., and Viana, A., 2015, Tracing mantle-

248 reacted fluids in magma-poor rifted margins: The example of Alpine Tethys rifted 
Publisher: GSA

Journal: GEOL: Geology

DOI:10.1130/G45530.1

margins: Geochemistry Geophysics Geosystems, v. 16, p. 3271-3308,

250 https://doi.org/10.1002/2015GC005830.

251 Schaltegger, U., Desmurs, L., Manatschal, G., Müntener, O., Meier, M., Frank, M., and

252 Bernoulli, D., 2002, The transition from rifting to sea-floor spreading within a

253 magma-poor rifted margin: field and isotopic constraints: Terra Nova, v. 14, p. 156-

$254 \quad$ 162, https://doi.org/10.1046/j.1365-3121.2002.00406.x.

255 Schwarzenbach, E.M., Früh-Green, G.L., Bernasconi, S.M., and Alt, J.C., 2013,

256 Serpentinization and carbon sequestration: A study of two ancient peridotite-hosted

257 hydrothermal systems: Chemical Geology, v. 351, p. 115-133,

258 https://doi.org/10.1016/j.chemgeo.2013.05.016.

259 Weissert, J.H., and Bernoulli, D., 1984, Oxygen isotope composition of calcite in Alpine

260 ophicarbonates: A hydrothermal or Alpine metamorphic signal?: Eclogae Geologicae

261 Helvetiae, v. 77, p. 29-43, https://doi.org/10.5169/seals-165497.

\section{FIGURE CAPTIONS}

263 Figure 1. A: Map of the major paleogeographic and tectonic units in the Alps (after

264 Schaltegger et al., 2002). B: Simplified geological map (after Desmurs et al., 2001) of the

265 study area. C: Line-drawing photograph of the Falotta outcrop, southeastern Switzerland.

266 Two decametric blocks of serpentinite have slipped down-slope. 

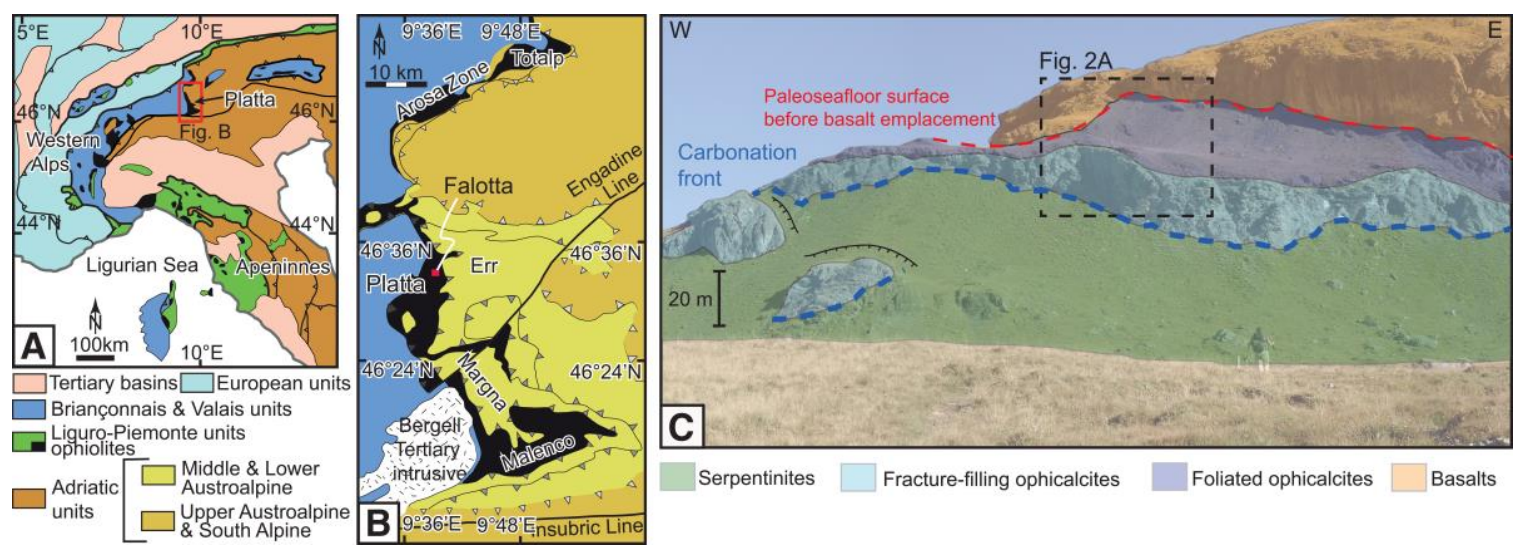

275 Figure 2. A: Schematic diagram illustrating the encountered lithologies at Falotta,

276 southeastern Switzerland (not to scale). In the serpentinite and ophicalcite units: SL-

277 serpentinite lenses; SB—-serpentinite breccias. In the basalt unit: $\mathrm{FH}$ —-foliated

278 hyaloclastites; FB — foliated basalts; VB — veined basalts; MB — massive basalts. See text

279 for details. B: Greenish serpentine vein crosscut by calcitic extensional veins (Cal EV) in

280 a serpentinite lens (photograph from a sliding block). C: Thin-section photograph

281 showing the greenschist alteration in the basalts [chlorite (Chl), epidote (Ep), quartz (Qtz)

282 and albite (Alb)] sealed by calcite (Cal) in a vein. D: Thin-section of a foliated

283 ophicalcite. Serpentine (serp) is replaced by calcite during fluid-assisted deformation

284 forming a gouge (Serp+Cal). Spinel grains (Sp) are destabilized. Actinolite (Act) and

285 hydro-andradite (h-An) grains accompany the alteration. E: Calcite pull-apart in foliated 286 ophicalcites. 
Publisher: GSA

Journal: GEOL: Geology

DOI:10.1130/G45530.1

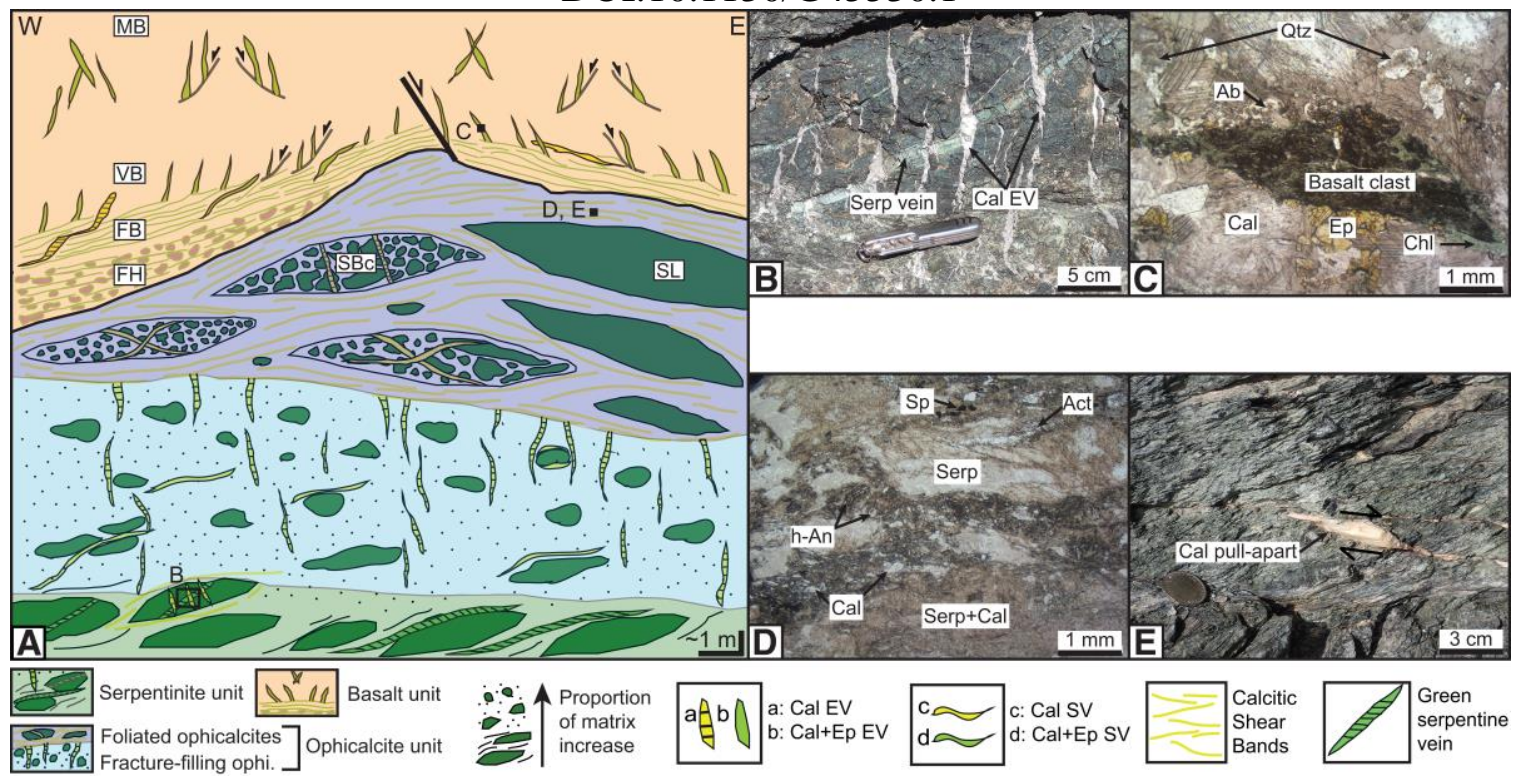

290 Figure 3. A: Synthetic log across the fossil detachment of Falotta, southeastern

291 Switzerland. B: Stereograms of vein poles (equal area, lower hemisphere, data number

292 N). See text for vein type abbreviations. C: $\delta^{18}$ O (VSMOW, Vienna Standard Mean

293 Ocean Water) and $\delta^{13} \mathrm{C}$ (VPDB, Vienna Pee Dee Belemnite) versus depth. 
Publisher: GSA

Journal: GEOL: Geology

DOI:10.1130/G45530.1

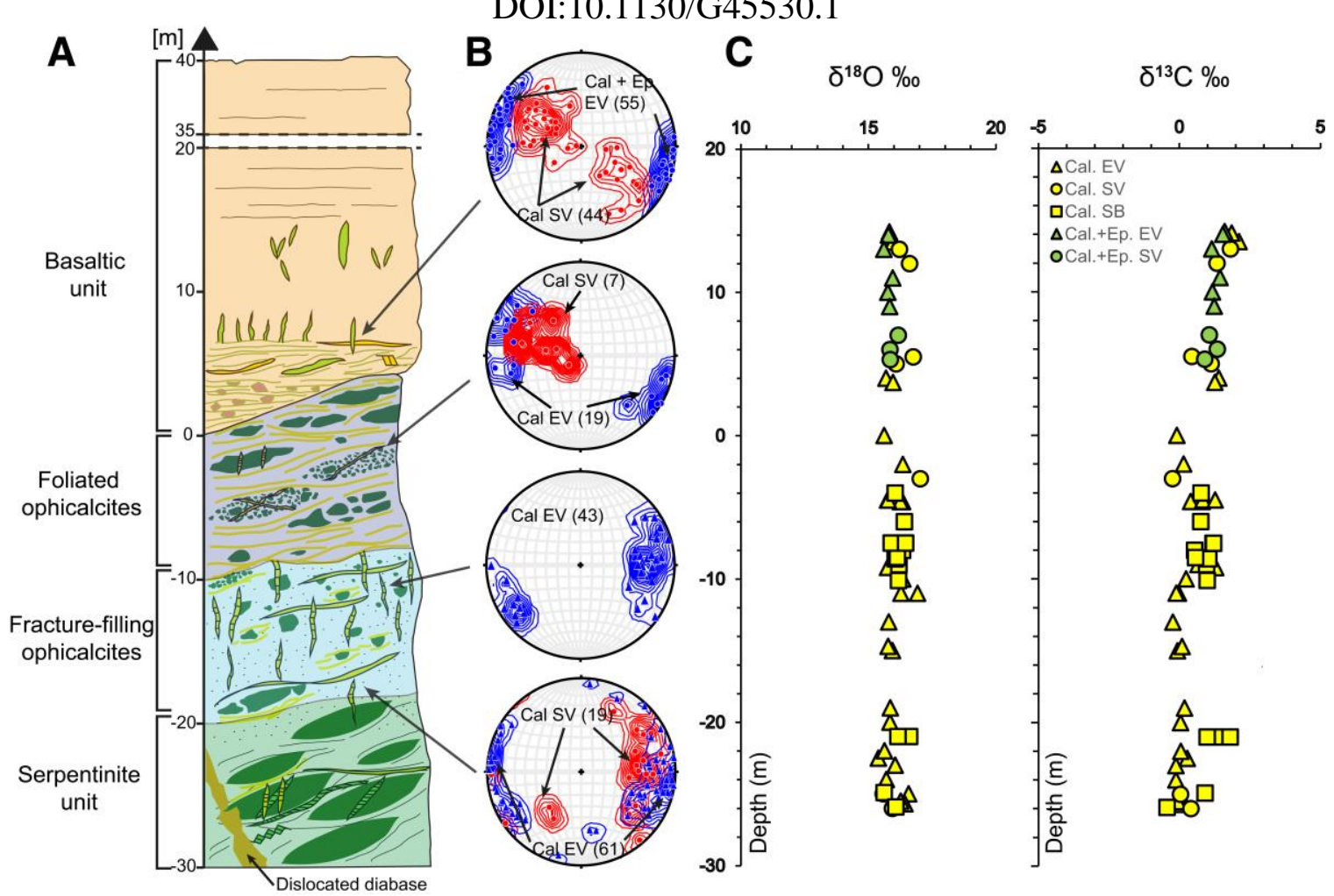

297 Figure 4. Model of carbonation (right-side sketch, I and II) in the context of magma-

298 assisted mantle exhumation (left-side sketch). Carbonation is represented in blue (veins).

299 Log scale, symbols and colors as in Figure 2. k- permeability. Adapted from Decarlis et

300 al. (2018). 
Publisher: GSA

Journal: GEOL: Geology

DOI:10.1130/G45530.1
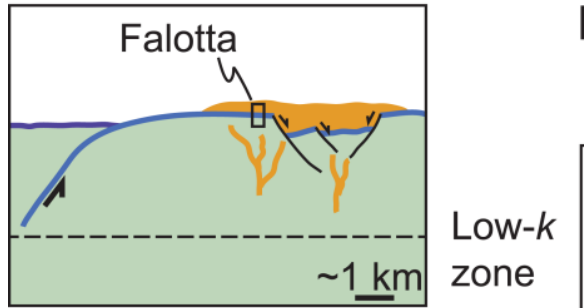

Lithospheric mantle

Basalts+ Intrusions

\Detachment

$\backslash$ Normal faults

' Serpentinization front

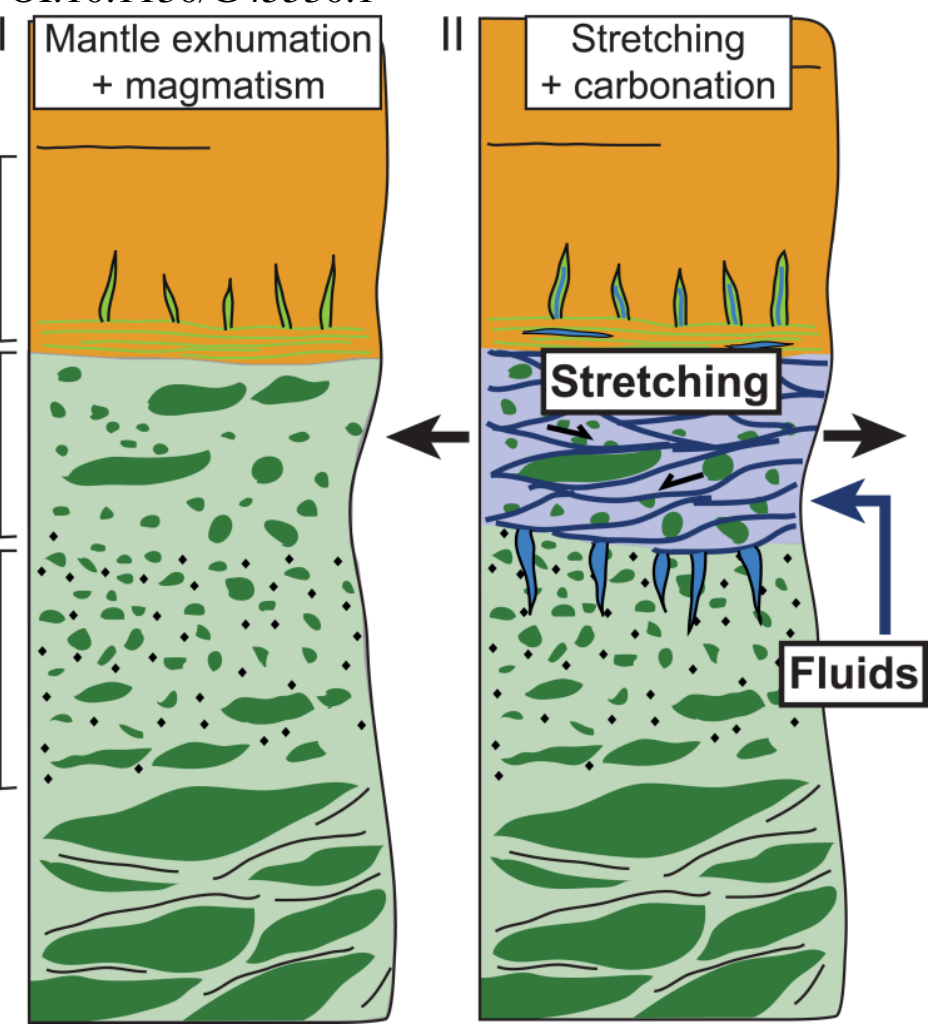

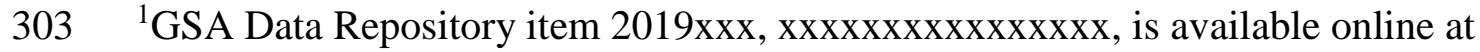

304 http://www.geosociety.org/datarepository/2019/, or on request from

305 editing@geosociety.org. 